\title{
Batik Jambi as a Reflection of Local Wisdom
}

\author{
Supana \\ \{supana_77@staff.uns.ac.id \} \\ Universitas Sebelas Maret Surakarta, Surakarta, Indonesia
}

\begin{abstract}
Indonesia has a variety of batik repertoire, then many areas in this country have batik with its each characteristic. Jambi as one of the provinces in Indonesia also has its own batik tradition. The richness and diversity of its flora and fauna color the variety of batik Jambi motifs. As Javanese batik filled with content of philosophical meaning, Batik Jambi also contains noble values as a reflection of the local wisdom of its people. This research tries to reveal the local wisdom contained in Batik Jambi.This research employs descriptive qualitative method. The method was conducted by describing the object of the study in detail and depth. The simplicity of Batik Jambi motifs in the form of separated paintings (ceplok-ceplok) and uncomplicated reflects a simple, egalitarian and open society to outside cultures. Local wisdom contained in Batik Jambi involves various aspects of life, including the relationship of human with God, human relationships with each other, noble behavior, how best to do something to achieve results, and the importance of welfare in the inner life. Batik Jambi is not only a cloth with a beautiful motive, but also a medium to preserve and conserve the local wisdom of its people.
\end{abstract}

Keywords: Batik Jambi, Motif, Local Wisdom

\section{INTRODUCTION}

Jambi as one of the provinces in Indonesia located on the island of Sumatra, as in other parts of Indonesia, has a wealth of distinctive artistic culture, which is different from other areas. The distinctiveness of Jambi culture can be seen not only in the art of dance, vocal, music, carving, and building but also its own peculiarities in its batik [1]. Batik in Jambi is called batik Jambi.

Batik was derived from the Javanese traditional sarong design [2].Batik Jambi tradition was firstly introduced by Haji Muhibat in 1875 [3]. He and his family came from Java and produced batik in Jambi. In the beginning Batik Jambi was used as a custom clothing by the nobility of the Jambi Sultanate. At that time Batik Jambi was only used by people who had high social life and economic ability, thus at first batik Jambi was less well known by the society at large.

Since the era of independence batik Jambi continues to grow rapidly[4], [5]. Now batik Jambi has been used by all circles of society and in all occasions. Batik Jambi can be used in various occasions and needs, such as for customs clothing and ceremonies (marriage ceremony, reading through al-Quran, haircut etc.), official events, uniforms of government and private institutions, school uniforms, and various also daily needs[6]. Until now batik Jambi tradition is still awake and growing. In Jambi there are places that became centers of 
batik production, among them in the city of Jambi, Batanghari, Soralangun, Merangin, Tebo and Bungo. The number of batik making centers show batik becoming part of Jambi society.

As time goes by, batik Jambi is also increasingly rich in motifs. Motives that have been there were not only increasingly varied on characters but also emerging new motives. The development of batik is not only related to the natural wealth, but also influenced by the sociocultural values of the people of Jambi. The richness of the natural environment is reflected in the variety of flora fauna in Jambi, while the sociocultural condition is related to the local wisdom that becomes the spirit of batik Jambi. Not many people are aware of the noble values contained in batik Jambi[7].

In addition, not everyone has the same understanding toward the meaning contained in batik[8]. One motif of batik cloth sometimes has a different meaning from different people[9]. The diversity of meaning interpretation on a piece of batik cloth reflects batik Jambi has a function to convey the noble values of its people. It also shows people's enthusiasm towards batik and the importance of planting the noble values of society through batik[10]. Assessment and introduction of local wisdom in batik well can strengthen the identity of society and reinforce the character of the nation.

\section{RESEARCH METHOD}

This research is qualitative as suggested by the theory of Lincoln and Guba [11], Patton [12], and Sutopo [13]. In order to maintain the validity of the data I used triangulation techniques, especially triangulation of sources

The strategy used in this study is a single case study strategy which leads to one characteristic of research activities. Technique of sampling in this research is purposive sampling.

Sources of research data in this study are documents and informants. Data collection technique was done by interview, observation and Content Analysis. Data Analysis Techniques in this research used interactive analysis, namely data reduction, data presentation, and verification [14]. In this analysis model, data reduction, data presentation, and the conclusion of activity were conducted in interactive form.

\section{RESULT AND DISCUSSION}

Batik owned by regions in Indonesia have motives, functions, and philosophical meanings that are not exactly the same. Each batik that exists in these areas have their own characters because batik is influenced by socio-cultural conditions and their natural environment. The condition of Jambi's natural environment reflected in the batik is visible with the motives of flora and fauna. Batik Jambi motif as a reflection of flora includes: bungomelati (jasmine flower), bungopauh (pauh flower), durenpecah(cracked durian), bungosawit (palm flower), bungobangkai (corpse flower), bungonago(dragon flower), daunkaret (rubber leaf), pohonrotan (rattan tree), mangosteen, jasmine leaves, kale leaf, bungojatuh (fallen flower), glass plate, bungobintang (star flower), kembangduren (durian flower), grapes, fungus, bungo kopi (coffee flower), bungotabur (sowed flower), pineapple, pineapple top, and so on. Here are some pictures of batik Jambi motif. 


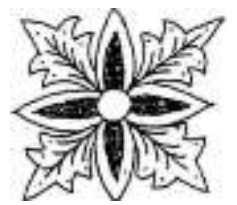

Figure 1. Motif bungamelati

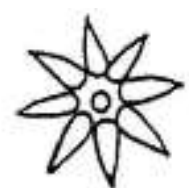

Figure 5. Motif bungatanjung

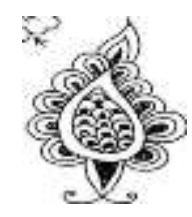

Figure 9. Motif bungapauh

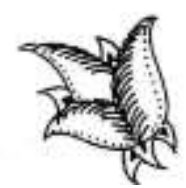

Figure 2. Motif antelas

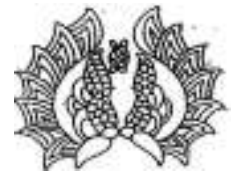

Figure 6. Motif durian pecah

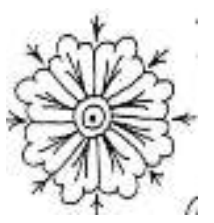

Figure 10.Motif bungakacapiring

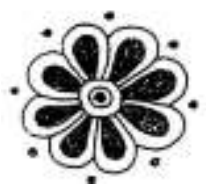

Figure 3. Motif tampukmanggis

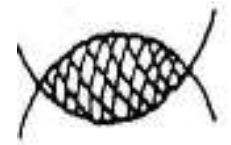

Figure 7. Motif bijimentimun

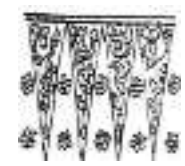

Figure 11. Motif pucukrebung

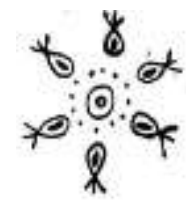

Figure 4. Motif

bungacengkeh

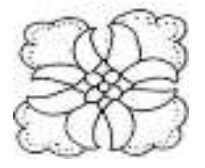

Figure 8. Motif bunga durian

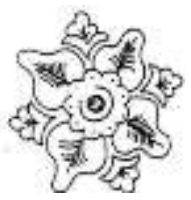

Figure 12.Motif bunga kopi
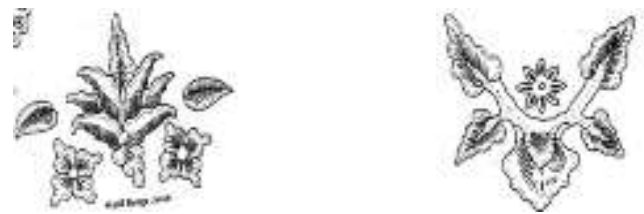

Figure 13. Motif bungajatuh Figure 14. Motif cendawan

Figure 15. Motif tampukmanggis

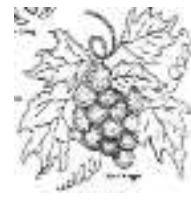

Figure 16. Motif anggur

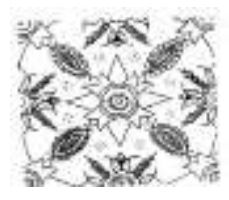

Figure 17.Motif bungobintang

There is a pattern of animals (fauna) or related to animals in batik Jambi, among others: kuauberhias (mirroring kuau), peacock, fish scales, snails, angso duo (two geese, shellfish, and so forth. Nevertheless, the pictures of animals in batik Jambi motifs are made distillate so that the animal shape does not look as obviously as a living animal. It is also related to the prohibition in Islam for not drawing living things. With this distillate, the figure of animals in 
the batik motif becomes blurred. Here is a picture of Jambi batik motif that has been distillated:

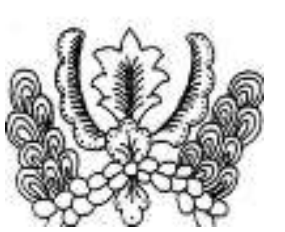

Figure 19. Motif merakngeram

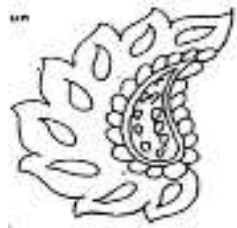

Figure 20. Motif kepak

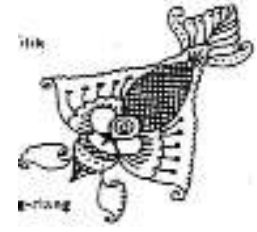

Figure 21. Motif riang-riang

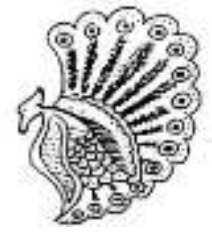

Figure 22. Motif burungkuaoberhias

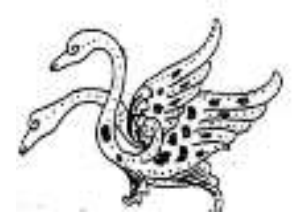

Figure 23. Motif angsadua

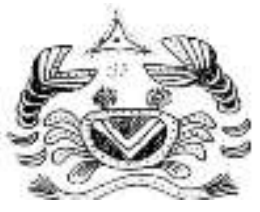

Figure 24.Motif kepiting

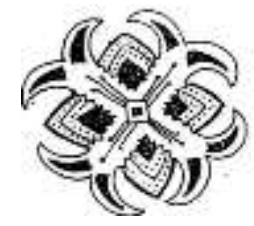

Figure 25. Motif supitudang

Batik Jambi patterned natural environment, among others: mountain, sun, Batanghari, and so forth. Batik motifs related to the livelihood include: kapalsanggat(sanggat ship), sailboat, boat, kapalpauh (pauh boat), and so on. Here are the pictures for the motive.

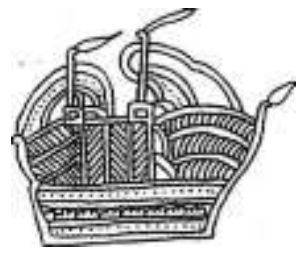

Figure 26. Motif kapalsenggat

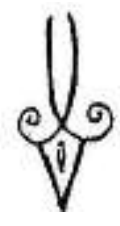

Figure 27. Motif jangkar

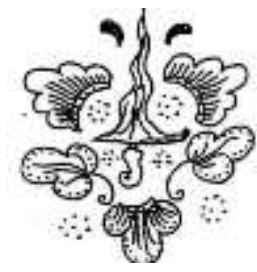

Figure 29. Motif kerissiginjai

Batik Jambi motif will continue to grow in line with the development of socio-cultural and the emergence of new batik motifs.

Batik Jambi motif is a motive that is not strung, each motif stands alone (ceplok-ceplok). The simplicity of Jambi's batik motifs reflects the character of Jambi people. That is a simple, egalitarian and open society to the outside culture, but rather slow to respond the change. This character is illustrated by displaying the uncomplicated and flexible elements of each motive. If then it appears an intricate batik Jambi and in complex details, it is a developed motif.

Giving motifs on batik Jambi was provided to every form of motifs, such as bungopauh motif in the form of pauh flowers, angsa duo motive in the form of painting two swans, kapalsenggatmotif in the form of a ship that is caught and so forth. A batik cloth contains several principal motifs, while the empty space between the principal motifs is filled with tabor titik motifs, tabor bengkok, and other stuffing motifs. Naming batik motifs in 
accordance with the basic motif. This is different from the Javanese batik motif, for example, giving batik motif based on a series of motifs on the fabric. Here is an example of batik Jambi motif.

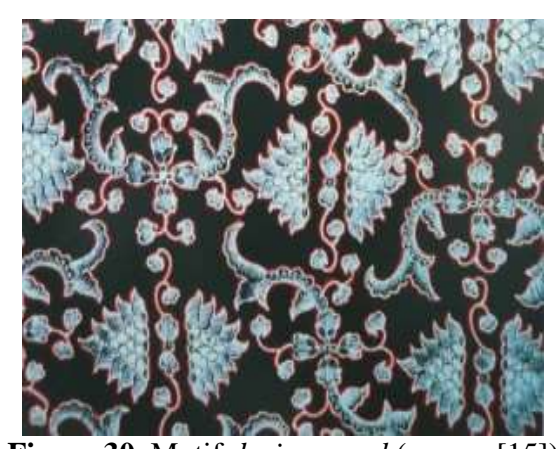

Figure 30. Motif durian pecah (source:[15])

Batik motif above is named durian pecah (cracked durian). This naming is due the dominant painting in the batik is a cracked durian. In addition to the picture durian pecah, in the motif of batik there are also paintings, leaves, flowers, and so forth. Another example is the batik motif of tampukmanggis.

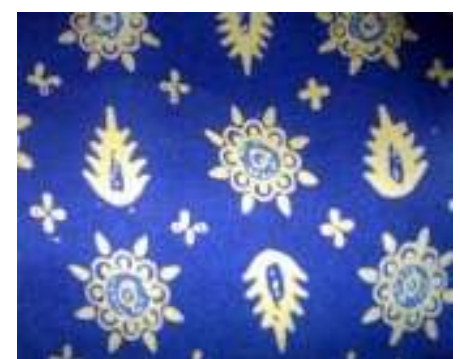

Figure 31. Tampukmanggis (source:[15])

The main motif in batik cloth is tampukmanggis(mangosteen). However, in the motif of tampukmanggis there are also pictures of leaves and stars. The leaves and stars are called stuffing.

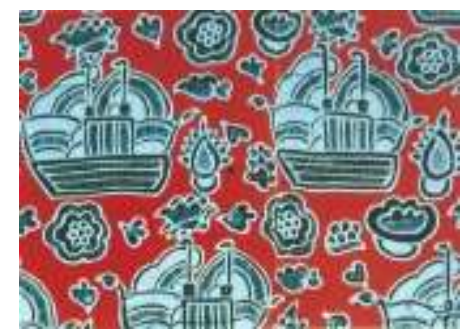

Figure 32. Kapalsenggat (source:[15])

Batik Jambi motif above is called kapalsenggatmotif because the main painting in the batik motif is a ship, senggat ship is a ship that was stranded. In the motive, the picture is not 
only paintings of the ship but also other paintings, such as pauh fruit, grapes, flowers, leaves, and so forth.

In its development it can also happen two main motives in one batik cloth. Such developments are mainly due to the market taste or consumers. The existence of batik producers is also influenced by consumers. Producers should not ignore the tastes of consumers if they do not want its existence faded. The emergence of two main motifs in one batik cloth certainly cause problems in naming. In addition, the suitability of the meaning of two main paintings contained in one batik cloth also brings its own problems.

The naming of batik Jambi motif is different from the naming of Javanese batik motif. Each series of images in a Javanese batik cloth is one motive, not the dominant motif in batik Jambi. Meanwhile batik Jambi motif is a motive that is not strung, each motif stands alone (ceplok-ceplok). The simplicity of batik Jambi motifs reflects the character of Jambi society, which is a simple, egalitarian and open society to the outside culture but rather slow to respond the change. This character is illustrated by displaying the uncomplicated and flexible elements of each motive.

Batik Jambi motifs as other batik are not only a beautifully painted fabric but also containing hope, prayer, education, and other social values. Batik Jambi motif contains philosophical meaning related to local wisdom of society.

Some motifs whose philosophical meaning have been known by the people including durian pecah motifs (cracked durian), tampukmanggis motifs, kapalsanggat(sanggat ship), kuauberhias (mirroring kuau) motifs, bijitimun (cucumber seeds) and so on. Durian pecah motif is in the form of durian paintings that splits but the base of the stalk is still interlocked. The painting of two durian skins has each meaning. The first part of the durian skin symbolically means the foundation of faith remember and be vigilant also able to keep something that has been good so as not to be damaged. This is a famous durian analogy which is delicious, that something as delicious as anything and piety while the other half is knowledge and technology. The intertwining of the durian hemisphere on the stem is symbolically meaningful that faith and piety also knowledge and technology cannot be separated. As a whole, the meaning of durian pecah motif is that all works must be based on faith and piety also supported by science and technology. The meaning of durian pecah motif shows that Jambi people uphold the value of faith and piety. This kind of value is certainly inseparable from the religious Jambi community. Durian pecah motif is also interpreted that we should always if it is damaged then it will not be worth anymore.

The tampukmanggis(mangosteen) motifs depicts the cross section of mangosteen peeled skin in the middle. This painting shows the outer skin, skin flesh and the contents of the fruit as a whole. Mangosteen skin color, skin flesh, and contents are different. Skin color and flesh skin are dark red, while the contents are white. The motive of this mangosteen symbolically implies that the goodness of manners and kindness of heart cannot be seen from the outer skin, judging a person not from his outward self, for example from the clothes worn and its appearance. The motive of mangosteen also means the existence of consistency between the body and soul. It is described the number of contents of the mangosteen fruit is equal to the number of petals on the cross section. If the number of petals on the cross section five, the contents also amounted to five. What he or she dictates must be in harmony with the hidden in his heart, one must be honest, not hypocritical. The motive of tampukmanggis is also associated with the teachings of Islam, especially with the five pillars of Islam. The number of petals on the mangosteen used in batik motifs in principle amounted to five in accordance with the pillars of Islam, although in practice sometimes it can be more than five. 
The motive of kapalsenggat is a painting of a ship that gets stuck on something while sailing which results in its journey disrupted and even stopped then it is unable to continue the journey. This motif symbolically implies that one must be careful in carrying out a job in order to finish well and no obstacles. He or she must understand and obey also be aware of the dangers that threaten him not to get an accident so that the work he or she does works well. The motive of kapalsenggat is also interpreted as a leader in carrying out his or her duties as a leader must be careful of the temptations, tests, and challenges that come and go. A leader is like a captain who does ship sailing in the ocean.Thus he or she must be alert to tides, waves, storms and typhoons that are likely to hit him or her. If the captain is not careful and alert, the ship will be shipwrecked. Motif of kappalsanggat also means that people in this life must have goals or ideals. People who have no purpose in life are like a ship that gets stuck so it does not reach its destination.

Batik motif of kuaoberhias(mirroring kuao) describes a kuao bird that was mirroring and flapping wings. The kuao bird is a beautiful bird and Jambi is one of its habitat. This mirroringkuao motif symbolically implies that one must know him or herself and always introspect. Human-being who knows him or herself, knows the nature of themselves, understands the advantages and disadvantages, will be able to put themselves well. By knowing yourself a person will be able to cover his or her shortcomings and increase also utilize the advantages it has. Meanwhile, the motif of pucukrebung(ornamental bamboo shoots) semioticly implies that one must have the ability to adapt and can do something useful. Like a bamboo tree, while still young (bamboo shoots) it can be used for vegetables. If it is old, then it can be used as a building material or make useful equipment.

The bijitimun (cucumber seed) motif in batik Jambi symbolizes the regeneration that is expected to continue and improve the existing life. Cucumber seeds also symbolize fertility and prosperity. In many batik cloths this functioned as a background, or isen-isen, but in Jambi this character is highlighted as the main motif. Meanwhile, the pattern of pauh flowers reflect the hope of fertility, health, wealth, and fortune that abound. Tawig ornament is taken from the existing architectural ornaments on the stage house in Jambi. This decorative nature reflects the character of a simple, egalitarian and open to things outside the environment yet full of awareness in responding to things from outside.

The motif of merakngeram (brooding peacock) illustrates that the responsibility, sacrifice and affection of a mother for her children is enormous. Therefore, a child must respect the parents and obey their command.

There are still various batik Jambi that have not been known the meaning. In its development it is possible that the existing motives will be given the content of noble values of the society. Batik never stop develops even always changes to follow the era and culture of society which make it [16]. That change is not only about the development of the motive but also the development or the addition of meaning contained in it. A batik motif not only has one meaning, motif of kapalsenggat, for example, has two meanings that someone must be careful in doing things so as not to harm. Another meaning is a leader must be vigilant in doing his job to succeed in leadership.

The meaning of batik Jambi motif involves various aspects, from the aspect of understanding the nature of human, the simplicity of attitude, the caution in acting, honesty, responsibility, not fascinated by the outward form, a life of inner and outer prosperity and so forth. The meaning contained in the batik motif is a form of local wisdom of Jambi people. The people of Jambi consider that it is important for a person to understand his or her nature. This good self-understanding can make a person places his or herself well, keep good 
relationship with God, keep good relationship with others, do something according to his own ability, improve self-ability and so on.

In doing something Jambi people are not only based on knowledge and technology skills but also on faith and piety. This shows that Jambi people is a religious society and religion becomes an important base in doing all activities. The importance of religion in the life of this society is reflected in the expression "adatbersendisyarakdansyarakbersendikitabullah". This seloka (archaic short witty poem ending in an aphorism) shows that Jambi culture is sourced from Al-Qur'an and Hadith, as a guideline for Muslims to live their life. It is not surprising, Jambi as one part of Malay culture cannot be separated with Islam. Judith [17] asserts that the relationship of Islam with Malay, including Jambi, occurs because Malay is one of several ethnic tribes where the religious identity and ethnicity are duplicate or overlapping. Religious identity is also a tribal identity.

In relation to each other, Jambi people uphold the nature of honest, simple, firm, straightforward, not judging a person from his or her birth only and so on. This simplicity and firmness stand with the straightforward style of Jambi people. People who do not understand the culture of Jambi may have heard when the people of Jambi are talking will be considered angry, whereas it is not. Jambi speech style shows the simplicity and assertiveness of community character. In relationships with parents especially with mothers, a child must respect and obey their commands, remembering so much of their parents' love and affection.

The people of Jambi as reflected by the meaning of batik motifs above do not neglect the outer life. A good life is a prosperous life both outwardly and inwardly, spiritually and materially, earning an abundant fortune. In addition, it is very important that life also look after the health of the body.

Local wisdom contained in batik Jambi involves various aspects of life, including the relationship of human with God, human relationships with each other, noble behavior, and inner welfare. Local wisdom in batik Jambi shows the influence of Islamic values. This is due Jambi culture, as part of Malay, is based on kitabullah (Al-Quran) and sunna of the prophet (Hadith). The influence of Islam is not only visible on the values contained in it. Batik Jambi motifs that mostly are the motifs of flora and fauna get a strong Islamic influence. In Islam it is forbidden to paint animate beings especially animals and humans. In batik Jambi there are some batik motifs with animal painting, for example kuao bird motif, angso duo (two swans), merakngeram (brooding peacock), crab, supitudang(shrimp pubis) and so on. The motifs of these animals are not drawn as they are but it has been distillated.Thus they do not resemble their original form. This is because Islam is forbidden to paint living creatures.

\section{CONCLUSIONS}

Batik which has been contained and developed in each region in the archipelago has its own characteristics that are influenced by the social and cultural conditions also surrounding natural environment. Batik is not only a beautiful painting on cloth but it reflects the local wisdom of its people. The value of local wisdom in batik Jambi involves various aspects of people's lives including the relationship of human beings with God and each other, how to behave appropriately, the highly upheld nature and so forth. The philosophical value of batik should be introduced to society to strengthen the values of morality in society. Batik with beautiful motifs can be a medium of instilling noble values to the community. 


\section{REFERENCES}

[1] Lembaga Adat Propinsi Jambi, Pokok-Pokok Adat Pucuk Jambi Sembilan Lurah. Jambi: Lembaga Adat Jambi, 2001.

[2] R. Legino and D. Forrest, "An Analysis of Javanese Influences on Malaysian Motifs in Batik Sarong Design," International Journal of the Arts in Society, vol. 6, no. 4, pp. 215-225, 2011.

[3] P. Supriono, Ensiklopedia: The Heritage of Batik. Yogyakarta: Andi, 2016.

[4] F. Kerlogue, "Batik cloths from Jambi, Sumatra," University of Hull, 1997.

[5] S. Adhanita, "Pengembangan Batik Jambi Motif Sungai Penuh sebagai Bentuk Kontribusi pada Pembangunan,” Jurnal Pembangunan Wilayah \& Kota, vol. 9, no. 4, p. 381, Dec. 2013.

[6] M. Hitchcock and F. Kerlogue, “Tourism, development and batik in Jambi," Indonesia and the Malay World, vol. 28, no. 82, pp. 221-242, Nov. 2000.

[7] A. Octavia, "Strategi Positioning Produk Batik Jambi," Jurnal Manajemen Terapan dan Keuangan, vol. 2, no. 3, 2013.

[8] W. Nuryanti and H. Minarti, Indonesian batik :transforming tradition into a modern trend contributors. Jakarta: Ministry of Culture and Tourism of the Republic of Indonesia, 2008.

[9] U. Yunus and D. Tulasi, "Batik semiotics as a media of communication in Java," Cultura. International Journal of Philosophy of Culture and Axiology, vol. 9, no. 2, pp. 143-150, 2012.

[10] E. Steelyana W, "Batik, a Beautiful Cultural Heritage that Preserve Culture and Support Economic Development in Indonesia," Binus Business Review, vol. 3, no. 1, 2012.

[11] Y. S. Lincoln and E. G. Guba, Naturalistic Inquiry. Beverly Hills, CA: Sage Publications, 1985.

[12] M. Q. Patton, Qualitative evaluation and research methods, 2nd ed. Newbury Park, CA: Sage Publications, Inc, 1990.

[13] H. Sutopo, Metodologi Penelitian Kualitatif. Surakarta: UNS Press, 2002.

[14] M. Miles and A. M. Huberman, Analisis Data Kualitatif (translated). Jakarta: UI Press, 1992.

[15] "Sejarah dan Ragam Motif Batik Jambi," Kemenag Jambi. [Online]. Available: https://jambi.kemenag.go.id/halaman/43/batik-khas-jambi.html 4/18/18.

[16] N. Djoemena, Ungkapan Sehelai Batik. Jakarta: Djambatan, 1990.

[17] A. N. Yudith, "What is The Malay? Situational Selection of Ethnic Identity on A Plural Sociaty,” American Etnologist, vol. 1, no. 2, pp. 331-350, 1974.

[18] K. Saddhono, S. T, Widodo, M. T. Al Makmun, and M. Tozu, "The study of philosophical meaning of batik and kimono motifs to foster collaborative creative industry." Asian Soc. Sci. vol. 10 no. 9 pp 52-61, 2014 